\title{
RAISED SHORE TERRACES AS THE RESULT OF CONTINUOUS REGRESSION
}

\author{
Nils Edelman \\ Institute of Geology and Mineralogy, Åbo Akademi, Åbo 2, Finland
}

\begin{abstract}
On two islands in the archipelago of SW Finland raised shore terraces lie at random altitudes on different shores, thus indicating that a standstill in regression is no prerequisite for the formation of shore terraces. This shows that a continuous process can give rise to a discontinuous result.
\end{abstract}

\section{Introduction}

Raised shore terraces have been used for studies of the post-glacial land uplift. As the rate of uplift varies in different parts of Finland, the warping of the raised shore lines gives a measure of the variations of the uplift in time and space. The apparent uplift or regression discussed here is the difference between the real uplift and the eustatic changes of the sea level. Some authors have assumed that the formation of shore terraces implies a standstill in regression and that well developed shore lines have only formed during breaks in the regression and that the corresponding shore lines can hence be classified as belonging to certain stages as e.g. Baltic Ice Lake III, Yoldia Sea IV etc. Some of these were in fact formed during a transgression or a standstill. Some observations in the archipelago of SW Finland point to the possibility of a terrace formation without any apparent standstill. Therefore a correlation of shore lines as synchronous merely on the basis of their altitudes above sea level seems doubtful.
Raised beaches on the island of Sandö $\left(60^{\circ}\right.$ $\left.2.0^{\prime} \mathrm{N}, 22^{\circ} 20.0^{\prime} \mathrm{E}\right)$, W of Kimito, and on the island of Sandskär $\left(60^{\circ} 6.3^{\prime} \mathrm{N}, 20^{\circ} 45.7^{\prime} \mathrm{E}\right)$, E of Sottunga, in the archipelago of SW Finland were studied. Both the islands consist of sorted glacifluvial sediments, principally of sand size. The grain size of the sediments seems to be somewhat coarser in Sandskär but each island consists of rather homogeneous material. This does not exclude the occurrence of local strings of shingle, pebbles and also some big boulders.

\section{Sandö}

Sandö belongs to a marginal moraine parallel to the Salpausselkä belt (See Fogelberg 1964). The island is about 2 kilometres long and 400 metres broad (Fig. 1). It is elongated in the direction $60^{\circ}$ and has a spit 300 metres long at the NE end. In the NW it is connected with a small island by a tombolo. The flat truncated top of Sandö lies about 14 metres above sea level and is inclined towards S or SW. From this 


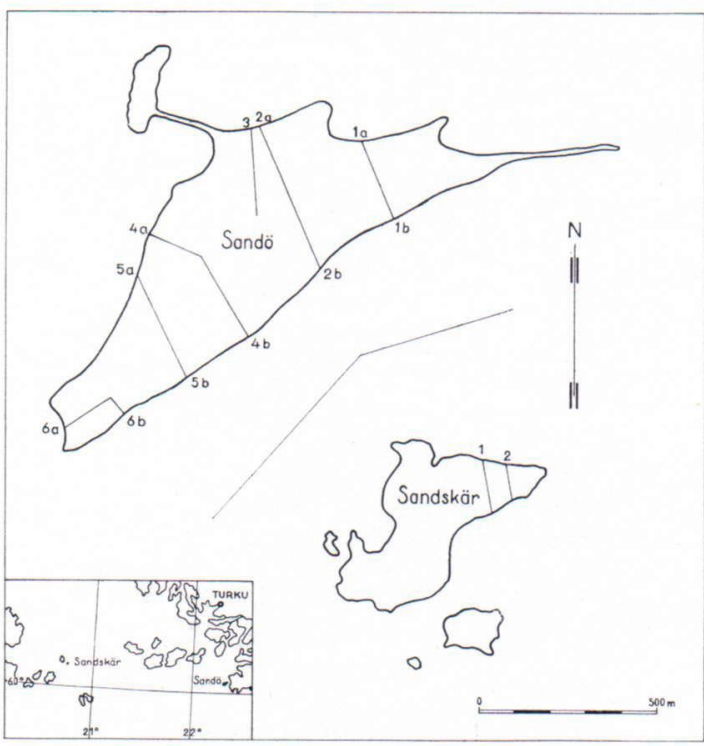

Fig. 1. Levelled profiles on Sandö and Sandskär.

platform the land surface sinks to the SE shore in a few conspicuous steps, well-developed raised shore terraces. Although the slope to the NW shore is smoother, a number of low terraces can be seen on it. The $\mathrm{N}$ border of the truncated top is an 8-9 metre high cliff which dips about $30^{\circ} \mathrm{N}$, the angle of repose of sand. There is a small remnant of a shore terrace on this cliff. The cliff is the highest on the island and the terrace below is the broadest, about 200 metres. However, it faces $\mathrm{N}$, in which direction the fetch is comparatively short and broken by several islands. Therefore it is inconceivable that this cliff and terrace could have been entirely cut by waves but it has of course been modified by the action of the sea. There must be another explanation for this cliff and the most probable one seems to be that the terrace is a primary feature formed during the deposition of the glacifluvial sediments and that the sea has only heaped up some sandy ridges on it. On the other hand the high cliff was probably formed by sand eroded from the top of the island and deposited on the leeward side when the top reached sea level about 2200 years ago (see Okko 1967, Fig. 7).
The sea has later cut terraces into this cliff of which only the small remnant mentioned above escaped total destruction during regression. The greatest fetch is against SW and S. When the typ of the island reached sea level most of the small skerries and islands, which nowadays form a breakwater against the Baltic sea, were below sea level so that waves from the Baltic reached Sandö. Today the SW wind has a fetch of about 25 kilometres and the NW wind one of 10 kilometres. The fetches of other winds are still shorter.

\section{Sandskär}

Sandskär, which lies E of Sottunga, seems to be part of a submerged esker which strikes about SE. It is about 600 metres long and 300 metres broad. The SW par of it consists of exposed Precambrian rocks whereas the NE part consists of glacifluvial sediments, principally sand, but also gravel and shingle. The directions of the greatest fetches are ESE for about 40 kilometres, ENE for about 30 kilometres, and NW, through a rather narrow strait, for 20 kilometres.

\section{Terraces}

The raised beaches are wave-cut platforms or, in some cases, wave-built terraces. In this paper they are called terraces. Some of them have sandy ridges on their edges sloping down to the terraces below. These wave-cut terraces developed differently in different parts of the islands. This is especially valid for Sandö where the terraces are very pronounced on the SE shore whereas on the NW shore they are much narrower and more closely spaced. Some profiles have been levelled over both the islands (Fig. 1). The altitudes of the raised beaches are seen in Figs. 2 and 3. The differences between the profiles are more striking than the similarities. Only one raised beach is noted on the same altitude on the profiles of Sandskär and none on those of Sandö. Even if the shore terraces vary in height 


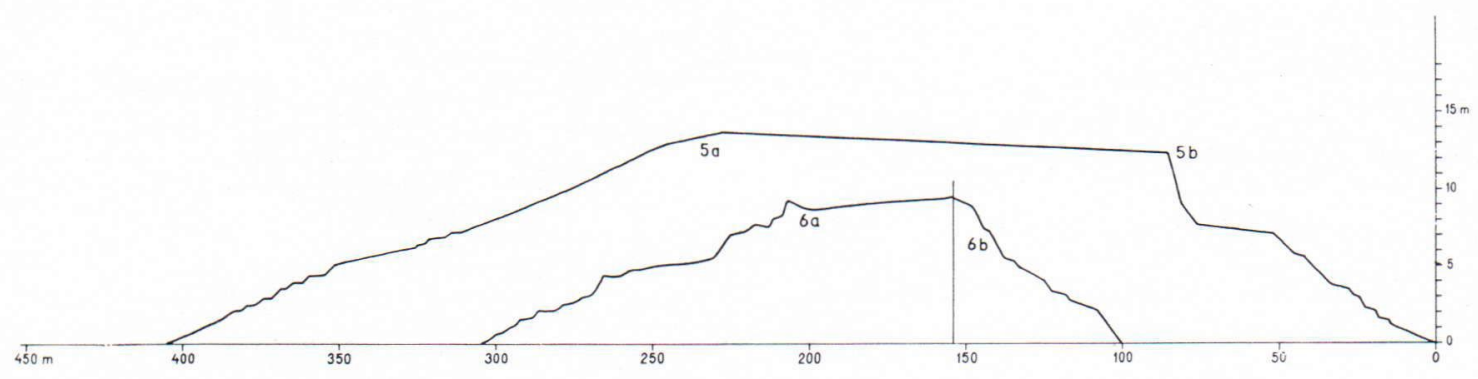

Fig. 2. Two profiles from Sandö. The height scale is 10 times the length scale.

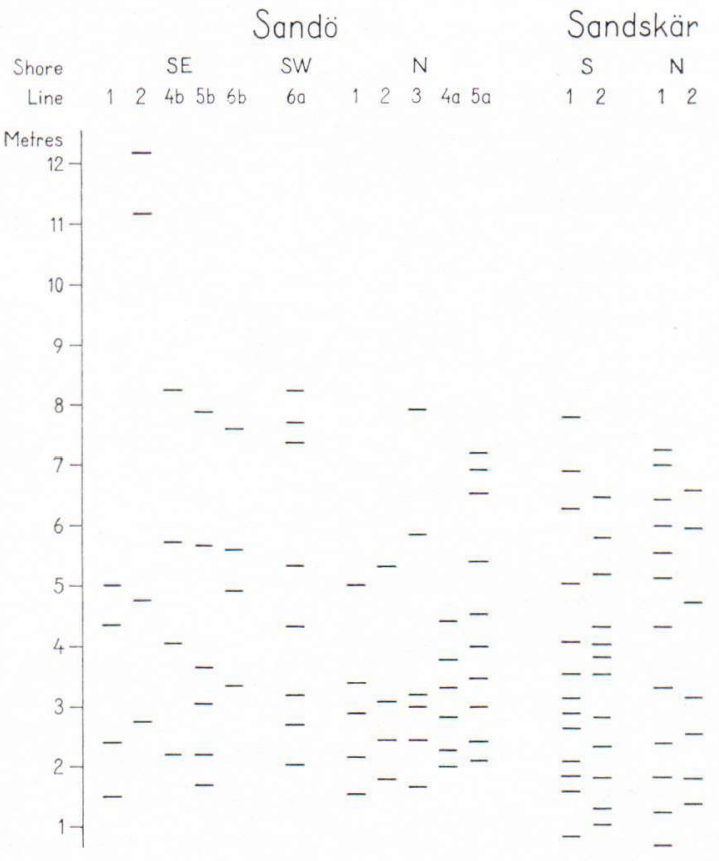

Fig. 3. Altitudes of the raised shore terraces on the profiles of Sandö and Sandskär.

due to local circumstances such as offshore bottom topography and exposition great difficulties arise when trying to connect terraces from different shores, because there may be two or three closely spaced terraces on one profile where there is only one terrace on another. In part of the slope between two terraces on the SE shore of Sandö there is a remnant of an interjacent terrace which was not entirely eroded away when the lower terrace was formed.

\section{Discussion}

There are raised beaches at almost every altitude on the islands in question. Only one terrace is observed in all the profiles of the same island, the 1.8 metre beach in Sandskär. If such terraces were formed only as the result of a stationary sea level one would expect to find terraces at almost the same altitude on at least one and the same island. The fact that the terraces have not developed on the same level around the islands is a strong argument against the hypothesis of a stationary shore level as a prerequisite for the formation of shore terraces. Scheidegger (1961, p. 237, referring to investigations of B. A. Popov) mentions that »shore platforms may also be formed if the change of sea level is slow and uniform». One of the arguments for supposing that the sea level has been stationary in relation to the land several times since the last glaciation is hence doubtful. One can assume that the apparent land uplift has been a continuous process at least of the scale discussed here, in agreement with, for instance, Ramsay (1931). This does not exclude the possibility that the land rises in small discontinuous steps of the magnitude of some millimetres or centimetres (Edelman 1949, Kujansuu 1964, Tynni 1965).

The formation of separate wave-cut terraces during a continuous negression can be explained in the following way. Waves over a certain size stir up the shore sand of which part is transported by currents along the shore where it forms spits, 
and part seawards where it builds up a terrace (Ingle 1966). Hence the waves cut a platform in the loose sand building a terrace and sand from the shore is transported into the sea. Per Bruun has explained the evolution of a shore during transgression (See Schwartz 1965) in a similar way. As this process continues, the rate decreases because the transport distance increases as the terrace grows broader. In the case of regression, the waves must cut the terrace down in order to keep it at the sea level. These processes will finally reach a point when the sea cannot transport enough sand away, and hence the abrasion of the waves will not be able keep pace with the rising land. The inner part of the terrace will come outside the wave action and become a raised beach whereas the outer edge of the terrace enter the zone of abrasion. The wavebuilt terrace will be worn down in the same way as the uplifted shore. After a time, the new terrace will have grown so broad that the waves and currents will not be able to transport enough sand away anymore and this second terrace will remain beyond the wave action. In this way discontinuous terraces will be formed although regression is a continuous process.

The formation of these shore terraces is aftected by a number of different factors and this explains why the height interval between adjacent terraces also varies in different parts of the same island (See Varjo 1964, pp. 89-93). The rate of land uplift is one of these factors. It has different values in different parts of Finland and has decreased very much since the end of the last glaciation. Another factor is the length of the fetch in different directions. Connected with this is the direction of winds exceeding Beaufort force 4. Hörnsten (1964) among others has shown that the uppermost shore line can vary several metres in altitude on the same hill owing to variations in the length of the fetch. The grain size of the glacifluvial sediments on the shores has modifying influence on the formation of the terraces. Also the primary gradient of the slope apparently has a great effect on the height interval of the terraces. On the SE shore of Sandö, where the primary slope is steeper than on the NW shore, the terraces are also fewer and the height interval between them accordingly greater (Fig. 2). Similar conditions occur on the island of Jurmo where the number and the height intervals of the terraces vary according to the slope angle as seen in Varjo's description (Varjo 1960, Fig. 4). The topography and the depth of the sea off the shore have of course a great effect upon the force of the breakers as well as upon the transport distance of the sand from the shore.

There may be still more factors than the above influencing the formation of the terraces. The quantitative effect of many of these factors or conditions is more or less unknown or very difficult to evaluate. It is especially difficult to estimate the topography of the bottom of the sea off the shore because it has changed continuously as the land rose and the loose sediments were eroded and redeposited by waves and currents. An attempt was made to establish a mathematical equation for the height interval between adjacent terraces as a function of the primary slope angle but the result was not encouraging, probably because the part played by other factors was difficult to evaluate and eliminate. This problem could possibly be solved by statistical treatment of much more extensive recorded material than that now available.

According to the present study, the shore terraces of the investigated islands were formed during a continuous regression and these terraces are no conclusive proof of any standstill in the regression.

Acknowledgements - I express my warm thanks to $\mathrm{Mr}$ Birger Ohlsson, assistant professor of geography, who has helped me in the field work and in the discussions. I should also like to thank Mrs Marjatta Okko, Ph. D., for reading the manuscript, and Mrs. Gillian Häkli for correcting the language. 


\section{REFERENCES}

Edelman, Nils (1949) Some Morphological Details of the Roches Moutonnées in the Archipelago of SW Finland. Bull. Comm. géol. Finlande, N:o 144, pp. 129 $-137$.

Fogelber G, PAul (1964) Om Salpausselkä III i Skärgårdshavet. Nordenskiöld-samf. tidskr., Årg. XXIV, pp. 36 -53 .

HöRnsten, Åke (1964) Ångermanlands kustland under isavsmältningen. Geol. Fören. Förh., Vol. 86, pp. 181 $-204$.

Ingle, James C. Jr. (1966) The Movement of Beach Sand. Elsevier, 221 p.

Kujansuu, Rarmo (1964) Nuorista siirroksista Lapissa. Geologi, Vuosik. 16, pp. 30-35.

Окко, Marjatta (1967) The Relation between Raised Shores and Recent Land Uplift in Finland during the Past 8000 Years Annal Acad. Scient. Fennicae, Ser. A, III Geol.-Geogr., N:o 93, pp. 1-59.
Ramsay, Wilhelm (1931) Material zur Kenntnis der spätglazialen Niveauverschiebungen in Finnland. Fennia, 54, N:o 3, pp. 1-145.

Scheidegger, Adrian E. (1961) Theoretical Geomorphology. Springer-Verlag, 333 p.

Schwartz, Maurice (1965) Laboratory Study of Sealevel Rise as a Cause of Shore Brosion. Jour. Geol., Vol. 73, pp. 528-534.

TrnnI, Rrsto (1965) Myöhäisglasiaalisia siirroksia Otaniemen kallioperässä. Geologi, Vuosik. 17, pp. 97-98.

VArjo, Uuno (1960) Die Steinwälle am Nordufer der Insel Jurmo. Zeitschr. Geomorph., Bd. 4, H. 3/4, pp. $246-263$.

- (1964) Über finnische Küsten und ihre Entstehung. Fennia, 91, N:o 2, pp. 1-104.

Manuscript received, December 14, 1967. 